\title{
Prevalence of Dyschromatopsias in the Academic Community of a Medicine School Course
}

\section{Prevalência de Discromatopsias na Comunidade Acadêmica de um Curso de Medicina}

\author{
Mateus da Silveira Cespedes*a; Tânia Gisela Biberg-Salumª; Rosilene Canavarros Monteiro ${ }^{\mathrm{b}}$

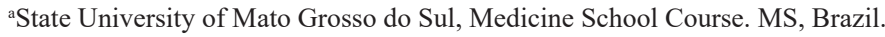 \\ ${ }^{\mathrm{b}}$ Anhanguera Uniderp University, Program in Science and Mathematics Teaching. MS, Brazil \\ *E-mail: mateus.cespedes@hotmail.com. \\ Recebido em: 17/08/2020 \\ Aprovado em: 19/11/2020
}

\begin{abstract}
Dyschromatopsia is defined as an abnormality of color vision, a deficiency that can cause difficulties in the day-to-day of some careers in the health area, including medicine, as it makes clinical practice difficult and may lead to potential errors. The objective was identify the presence of Dyschromatopsias in the student and teaching community of UEMS Medicine School course and the repercussions they bring to the performance of activities related to medical activity. It is a quantitative, observational, cross-sectional and descriptive research. 160 individuals were evaluated, including Medicine School students and professors at the campus of UEMS - Campo Grande Unit, by reading pseudo-isochromatic slides from the Book of Ishihara. Data were tabulated in Excel and analyzed using non-parametric statistics. Of the 160 volunteers, 25 were professors (15.6\%) and 135 students (84.3\%). Most were female. Only 02 of the 58 volunteers (1.25\%) surveyed, had color vision deficiency. Both patients with dyschromatopsia were already aware of their clinical conditions, and were classified in the research as having Deutan deficiency (green, red-green by Ishihara plates 16 and 17). The participants denied having a family history of this disease and both reported difficulties in the microscopies study and during medical prescriptions, due to the color of the pens to be used. The prevalence of Dyschromatopsias was $1.25 \%$, and the 2 affected participants in the medical field already had knowledge of their disability.
\end{abstract}

Keywords: Color Vision Defects. Medicine School Students. Epidemiology. Competency-Based Education.

\section{Resumo}

Discromatopsia é definida como anormalidade da visão das cores, deficiência esta que pode causar dificuldades no dia-a-dia de algumas carreiras da área da saúde, incluindo medicina, pois dificulta a prática clínica e pode levar a potenciais erros. O objetivo foi identificar a presença de discromatopsias na comunidade discente e docente do curso de Medicina da UEMS e a repercussão que estas trazem para o desempenho das atividades relativas à atividade médica. Trata-se de uma pesquisa quantitativa, observacional, transversal e descritiva. Avaliou-se 160 indivíduos entre discentes e docentes de medicina do campus da UEMS - Unidade Campo Grande através da leitura de lâminas pseudo-isocromáticas do Livro de Ishihara. Dados foram tabulados em Excel e analisados via estatística não paramétrica. Dos 160 voluntários, 25 eram docentes (15,6\%) e 135 discentes (84,3\%), sendo que a maioria pertencia ao sexo feminino. Apenas 02 dos 58 voluntários $(1,25 \%)$ pesquisados, apresentaram deficiência da visão de cores. Ambos os portadores de discromatopsia possuíam conhecimento de suas condições clínicas, e foram classificados na pesquisa como tendo deficiência Deutan (verde, vermelho-verde pelas placas 16 e 17 de Ishihara). Os participantes negaram ter histórico familiar deste acometimento e ambos referiram dificuldades no estudo das microscopias e durante as prescrições médicas, devido à cor das canetas a serem utilizadas. A prevalência das discromatopsias foi de 1,25\%, e os 2 participantes afetados no meio médico já apresentavam conhecimento de sua deficiência.

Palavras-chave: Defeitos da Visão Cromativa. Estudantes de Medicina. Epidemiologia. Educação Baseada em Competências.

\section{Introduction}

Dyschromatopsia means the abnormality in the colors vision. This deficiency may cause problems in everyday life and in some professions, such as medicine, for example, may make it difficult to perform daily activities, such as clinical practice itself, and may favor potential misunderstandings ${ }^{1}$. It is a disease whose study becomes valuable in order to understand the processing of such a phenomenon in the different individuals, normal or daltonic, since the colors perfect perception interferes with the individual's interaction with his or her environment and social environment ${ }^{2}$.

In 1798, Dalton became the first to describe the change in the colors vision, characterizing his own condition, popularly known as "daltonism"2. For medical science, any change in color visualization is called dyschromatopsia, and the cones are responsible for central vision and color. These are photoreceptor cells, as well as the rods, which constitute the receptors of light stimuli ${ }^{3}$. The cones differ from the rods because they selectively respond to certain colors, because they are less sensitive to light and because they are connected to optic nerve fibers in the proportion of a cone to a fiber, which allows much greater visual acuity ${ }^{4}$.

The colors vision follows the trichromatic theory, which describes the existence of three classes of cones in the retina, whose ability to distinguish the colors depends on a pigment, opsin, different pigments that absorb photons with 
long wavelength $(560 \mathrm{~nm})$ are those sensitive to red, medium wavelengths $(530 \mathrm{~nm})$, sensitive to green and short wavelength (430nm), sensitive to blue ${ }^{5}$.

The normal chromatic perception is therefore the result of the visual sensation of the messages from the three categories of normal photoreceptors ${ }^{6}$. Opsin is responsible for the electrons rearrangement in the retina, converting energy into neuronal impulse, which is transmitted through synapses to the visual cortex. At this site, the predominant wavelength is distinguished from the others and results in the tone perceived by the individual? .

Due to the existence of three different types of cones, it is considered, in this theory, that humans with a normal color vision are called trichromats, and there may be the anomalous trichromats. When only two pigments are functional, they are classified as dichromats and, with only one, monochromats, which are truly blind to colors ${ }^{8}$.

Dyschromatopsia or chromatic sensitivity defect may also be classified as a congenital or acquired alteration ${ }^{3}$. The genes for the green and red colors are linked to sex and are on chromosome $\mathrm{X}$. on the other hand, the gene for the blue color is on chromosome $7^{5}$. Thus, blindness to congenital colors more rarely occurs in females, since at least one of the two $\mathrm{X}$ chromosomes will probably have the normal gene for each type of cone ${ }^{3}$. Congenital disorders are caused by alterations in the opsins encoder genes. In these cases, discrimination errors are specific to a certain range of light spectrum. In common, the individual presents impairment in both eyes, with good visual acuity, but congenital dyschromatopsias are irreversible, not susceptible to treatment or prophylaxis, and do not present any ${ }^{3}$ progressive character. Red and green deficiency is the most frequent one, $\mathrm{X}$-linked recessive inherited ${ }^{9}$ and, therefore, more frequent in males. It reaches about $8 \%$ of Caucasian men, 4 to $5 \%$ of Asian men and $4 \%$ of African and Native American men, and Caucasian women are $0.5 \%$ of dyschromatopsia cases ${ }^{1}$.

Acquired disorders, in turn, also affect men and women, being more rare than those of congenital cause, and are caused by brain or optic nerve lesions (optic neuritis), macular diseases, retinal diseases (retinitis pigmentosa), diabetic neuropathy, avitaminosis (vitamin A) or traumas ${ }^{9,11,12}$. In these cases, the chromatic deficit may be unilateral or limited, may be closely related to other impairments of the visual functions (visual acuity, adaptation) and may evolve according to the lesion that conditions it, improving or progressing. Generally, in the acquired dyschromatopsia, the deficiency is usually for yellow and blue and in the congenital for red and green ${ }^{2}$.

Changes in color perception may be light, mild or severe, and the possible complications resulting from them may vary depending on the severity and type of dyschromatopsia, determining the level of impairment in the activities of each affected individual. It is also considered that there is a subjective evaluation by each person regarding the problems triggered by the chromatic defect in their daily life, which may depend on several factors ${ }^{18}$.

For the study of the colors vision there are numerous methods, the most used being the Nagel anomaloscope, Farnsworth tests and pseudo-isochromatic boards. It is published, as being the simplest and most accessible method among these, that of pseudo-isochromatic plates or boards, represented by the Ishihara Test, as being the most known and used in the world ${ }^{2,12,13}$. Studies have shown that this test remains the most effective ("gold standard") for the rapid identification of congenital deficiencies for the colors vision'. This is a demonstration test, carried out with a series of polychromatic plates, made up of points in primary colors, printed on a background of similar points, organized by chance by brightness, in a way that it is impossible for a person with a color deficiency to perceive the number hidden in the matrix. It is inexpensive and portable, and can be completed in less than five minutes.

Among the purposes for the study of the color vision in individuals, the possibilities for the screening of defects, characterization of the type and severity of defects, differentiation between congenital and acquired cases, and also the orientation regarding vocational tests are highlighted ${ }^{14}$. It is important to diagnose the Dyschromatopsias since childhood, so that it is possible to carry out the child's professional orientation, knowing that some professions depend, in an inherent way for their satisfactory implementation, on good color vision, such as transport workers, telecommunications, military services and others ${ }^{11,14}$.

Thus, the objective of this study was identify the presence of Dyschromatopsias in the student and teaching community of Medicine School course ( UEMS) and verify the repercussions they bring to the performance of activities related to medical activity.

\section{Material and Methods}

It is a quantitative, observational, cross-sectional and descriptive research. It was developed in a block of Medicine School Course of the State University of Mato Grosso do Sul (UEMS) - Campo Grande Unit, a frequent co-existence place of the teaching and student communities of the medicine school course.

All professors of the medicine school course and all students, adults and duly enrolled in the medicine school course of the State University of Mato Grosso do Sul (University Unit of Campo Grande), totaling 226 volunteers (192 students and 40 professors), were included. From these, students who were not actively studying the medicine school course (12) were excluded, those who refused for any reason to participate voluntarily in the research (30) and those who could not be contacted (15). The professors who were not in the area of health sciences, as well as those who could not be contacted (18) or did not express their agreement by signing 
the TCLE were excluded (2). The total surveyed sample consisted of 160 participants.

The data were obtained by applying the Ishihara Test and the data collection was carried out primarily by the academic researcher, who was previously qualified by the ophthalmologist, co-author of this study, regarding the technique for performing the test.

The participants were evaluated using the simplified and modified edition of the book of Ishihara, which consists of eight pseudo-isochromatic slides. A letter or number is formed depending on the disks layout, tone, saturation, and brightness. The students and professors were submitted to screening with the basic test and the suspected cases were reassessed by the specialist with the complete 38-slide test, which favors the dyschromatopsia classes detection .

The individual test was applied to the volunteers in an illuminated and private room to maintain the secrecy regarding the outcome of the test. Under binocular vision, each slide was presented, for a period from 3 to 5 seconds, at a distance of approximately $35 \mathrm{~cm}$ from the examined eye, under natural daylighting. When necessary, the examined student or professor used corrective lenses (glasses or contact lenses). The same test could be repeated more than once, if necessary, for those who demonstrated some alteration to the examination and, for those who obtained a positive test, referral was arranged for re-evaluation by the specialist in order to confirm the diagnosis.

For the students and professors with confirmed diagnosis, a self-applicable questionnaire was presented, consisting of two closed and one open questions, which addressed the presence or absence of family history of dyschromatopsia, prior knowledge about the pathology existence and possible difficulties in the professional field.

The data collected were organized in spreadsheets of Microsoft Excel ${ }^{\circledR} 2010$ program, for later analysis in tables and graphs. Correlations were made among the variables by means of non-parametric statistics, using the advanced program functions.

The protocol of this research was approved by the Research Ethics Committee through the CAAE deliberation: 79421217.6.0000.8030. Volunteers under 18 years of age were excluded. All the participants were oriented, consented and adequately completed the Free and Informed Consent Term (TCLE).

\section{Results and Discussion}

After acceptance and signing the TCLE, 160 volunteers were evaluated. Among these, 25 were professors and 135 students. Of the total sample, $58.75 \%$ were female and $41.25 \%$ were male (Table 1). Despite the literature demonstrating a massive prevalence of cases of dyschromatopsias in the male sex, the proportion between patients of this sex and female patients impaired in a congenital form of around 100:1 12,14,15, even though, mainly if the presence of acquired chromatic defects is considered, positive cases are found in the female sex, which justifies the choice of the sample being composed of both sexes.

Table 1 - Distribution between sex and age of volunteers

\begin{tabular}{|c|c|c|c|}
\hline $\begin{array}{c}\text { Academic } \\
\text { Degree }\end{array}$ & Male & Female & Total \\
\hline Students & $52(32.5 \%)$ & $83(51.87 \%)$ & $135(84.3 \%)$ \\
\hline Professors & $14(8.75 \%)$ & $11(6.87 \%)$ & $25(15.6 \%)$ \\
\hline Total & $66(41.25 \%)$ & $94(58.7 \%)$ & $160(100 \%)$ \\
\hline
\end{tabular}

Source: Research data.

Among the 160 volunteers evaluated, two of them presented color vision deficiency, that is, positivity for dyschromatopsia and both were male sex. The prevalence of patients bearing Dyschromatopsia obtained in this study (1.25\%) and its distribution by sex corroborates the current medical literature, which indicates numbers ranging from 2.5 to 4.87 , in samples between 604 and 3124 investigated, although classically, the numbers vary from 1 to $8 \%$, considering the different ethnic groups ${ }^{14-17}$. In a screening study for ametropias and Dyschromatopsias in students of the municipal network of the same municipality, whose ages ranged from 7 to 19 years, the prevalence of color vision impairments was $2.17 \%{ }^{18}$. The responses to the Ishihara test of the impaired volunteers are expressed in Table 2.

Table 2 - Results of volunteers number 1 and 2 bearing Dyschromatopsia

\begin{tabular}{|c|c|c|c|c|}
\hline Plate & $\begin{array}{c}\text { Result of } \\
\text { Volunteer } \\
\mathbf{1}\end{array}$ & $\begin{array}{c}\text { Result of } \\
\text { Volunteer } \\
\mathbf{2}\end{array}$ & $\begin{array}{c}\text { Expected } \\
\text { Normal } \\
\text { Result }\end{array}$ & $\begin{array}{c}\text { Expected } \\
\text { Changed } \\
\text { Result }\end{array}$ \\
\hline Plate 1 & 12 & 12 & 12 & 12 \\
\hline Plate 2 & 3 & 3 & 8 & 3 \\
\hline Plate 3 & 10 & 70 & 29 & 70 \\
\hline Plate 4 & 2 & 2 & 5 & 2 \\
\hline Plate 5 & $\mathrm{X}$ & 5 & 3 & 5 \\
\hline Plate 6 & $\mathrm{X}$ & 17 & 15 & 17 \\
\hline Plate 7 & 21 & 27 & 74 & 21 \\
\hline Plate 8 & $\mathrm{X}$ & $\mathrm{X}$ & 6 & $\mathrm{X}$ \\
\hline Plate 9 & $\mathrm{X}$ & $\mathrm{X}$ & 45 & $\mathrm{X}$ \\
\hline Plate 10 & $\mathrm{X}$ & $\mathrm{X}$ & 5 & $\mathrm{X}$ \\
\hline Plate 11 & $\mathrm{X}$ & $\mathrm{X}$ & 7 & $\mathrm{X}$ \\
\hline Plate 12 & $\mathrm{X}$ & $\mathrm{X}$ & 16 & $\mathrm{X}$ \\
\hline Plate 13 & $\mathrm{X}$ & $\mathrm{X}$ & 73 & $\mathrm{X}$ \\
\hline Plate 14 & $\mathrm{X}$ & 5 & $\mathrm{X}$ & 5 \\
\hline Plate 15 & 45 & 45 & $\mathrm{X}$ & 45 \\
\hline Plate 16 & 2 & 2 & 26 & 2 (Deutan \\
\hline Plate 17 & 8 & 4 & 42 & 4 (Complete \\
\hline Source $\mathrm{Res}$ & & & & Deutan ) \\
\hline
\end{tabular}

Source: Research data.

It was also found in positive cases that both are classified as having a deutan-type impairment. Among the various classifications of dyschromatopsias and taking into account the trichromatic theory, individuals may be classified as trichromat (normal or abnormal: protanomalous, deuteranomalous, tritanomalous), dichromat (protanope, 
deuteranope, tritanope) or monochromat (typical or atypical) ${ }^{19}$. Defined by convention, the Greek prefixes for first, second and third "protos", "deuteros" and "tritos" are used to determine the red, green and blue colors, respectively, when naming the color vision impairments ${ }^{1}$, thus emphasizing that the two participants of this research who presented an impairment in the color vision present the type "blindness to green".

During the general application of the test, it was noticed that, for the response of some plates, the participants demanded greater attention or hesitated and even showed confusion and even error in the definition of the number seen. The images that most led to doubts with the volunteers, even those without dyschromatopsia, were plates 17 (11 errors, usually replacing 73 with 78,13 with 18) and 7 (4 errors, all replacing the number 3 with the number 8) (Figure 1). Considering this observation that was arisen and investigated in the present study, no references to this approach were found in the other literary texts, highlighting the plates specificity that stimulated greater difficulty in reading and number of errors, for the sample as a whole. This leads us to speculate that the format of the numbers presentation may be one of the generators of such difficulties and misunderstandings.

Figures 1 - a) Plates 17 (73) and b) 6 (5) of Ishihara Test with 38 plates. a)

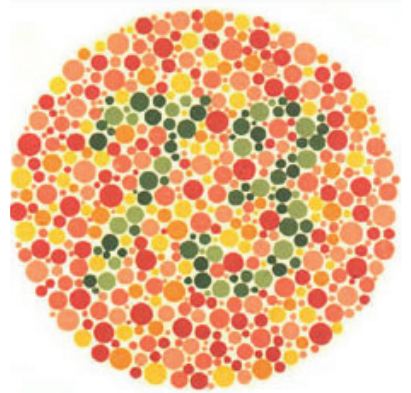

b)

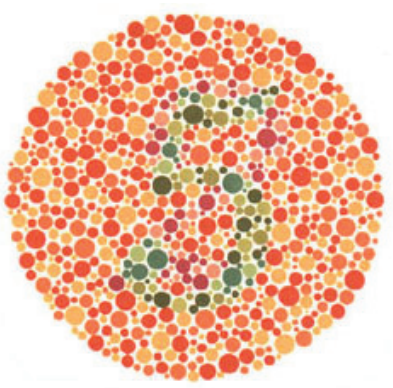

Source: www.color-blindness.com/ishiharas-test-for-colour-deficiency38-plates-edition.

The trichromat volunteers presented an error rate below 1 plate per test and, according to the author of the test, the evaluation should be negative in case the tested volunteer shows up to 7 reading errors ${ }^{26}$. The data are expressed in Figure 42

Figure 2 - Errors in plates reading (non-dyschromatopsia bearers) Doubts at the plates

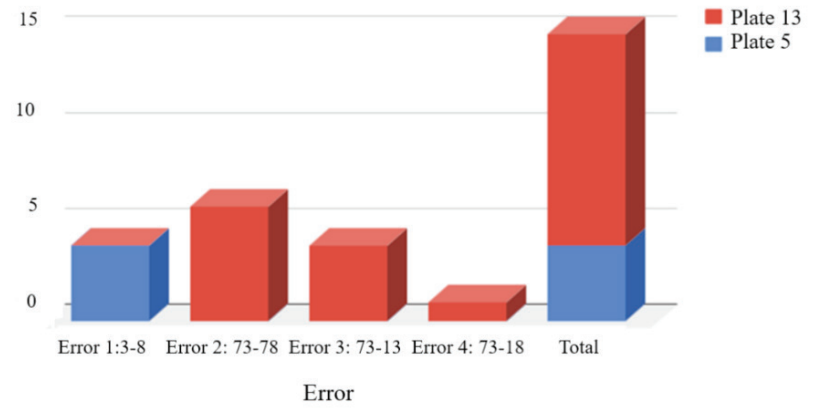

Source: Research data.
Regarding the questionnaire that asked about the previous pathology knowledge, both positive cases reported already being aware of their clinical condition. Although the present study has the sample restricted to participants in the medicine school course, it is known that, in the students in the area of health, the previous knowledge regarding the pathology portability is greater than the general population, in a proportion of $81.2 \%$ for the former and $20 \%$ for the general population, according to study by Neumaier ${ }^{15}$.

The two participants with chromatic defect denied having a positive family history for this impairment, and this information is configured as a little explored information in the literature, even if the heredity associated with genes is present, since the genetic material responsible for the photopsins codification belongs to a family that includes the smell and taste receptors. Two studies indicate that dyschromatopsias bearing patients reported on family history, and an estimate of $62.5 \%$ of positive cases of color disorders was found in relatives of first and second degrees ${ }^{1,16}$.

Regarding the question that investigated about possible difficulties in the performance of professional activities, both referred to presenting some difficulty in the study of microscopies/histopathological aspects and during medical prescriptions, related to the color of the pen to be used, although they did not relate obstacles to the performance of physical or complementary examinations.

In a literature review study, it was found that, in medical practice, difficulties related to skin color, microscopy, ophthalmoscopy and otoscopy alterations were the most observed ones. In addition, some of these professionals presented limitation in the visualization of blood or bile in secretions of the gastrointestinal and genitourinary tract. The study also points out that many of these physicians, who participated in the research, were unaware of bearing any impairment. It draws attention to the comment of a physician who participated in one of the studies on dyschromatopsia, transcribed as follows: "My loss of confidence might have been more sympathetically handled had they [my teachers] been on the lookout for this problem" ${ }^{12}$.

Dyschromatopsia is still little approached currently and there is a shortage of work on the subject. The fact that there is no definitive treatment corroborates this lack of knowledge. Other studies are needed to seek greater information and a better way to deal with this problem in our environment, which includes a poorly evaluated population ${ }^{14}$.

About the academic-professional difficulties of the impaired individuals, studies found brought this merit, addressing a lower general academic performance in the evaluated disciplines, difficulty in reading tables/graphs/ images of scientific articles, in addition to the difficulty in identifying histological slides ${ }^{20-25}$.

On the other hand, there are reports of physicians who have such a deficiency that, in order to highlight the difficulties encountered, they become even more detailed and observe 
the clinical history of their patients, even seeking assistance from colleagues to minimize the possibility of errors in the diagnoses $^{8}$.

Although colors are indispensable in teaching-learning processes, there is no associative evidence between dyschromatopsia and educational level, which is a conclusion of an extensive British cohort study ${ }^{27}$. This study showed the possibility raised in a previous case-control study, which compared the prevalence of Dyschromatopsia among students with intellectual disabilities and students without cognitive impairments $^{28}$.

In addition to the pedagogical and/or labor difficulties faced by the bearers, there are subjective discomforts that can be faced at any educational level or professional practice, resulting in changes in their interpersonal relationships, such as shame and anxiety before excessive curiosity of colleagues ${ }^{29}$.

\section{Conclusion}

Through this study, it was possible to show that dyschromatopsia can cause impacts, both in the students' daily life and in the performance of professional activities.

The prevalence of $1.25 \%$ of dyschromatopsias in the students and professors population was found to date. Of this total, all the impaired patients had prior knowledge on the pathology and there was no confirmation of family history in patients with dyschromatopsia.

Color identification is a physiological process that, when impaired, needs early medical diagnosis in order to adopt measures that minimize its effects.

\section{References}

1. Adam Netto A, Neumier R, Rodrigues IK, Astolfi M, Santa Ritta RA Aguiar U. Prevalência de discromatopsia em estudantes de medicina da Universidade Federal de Santa Catarina. Arq Catarinenses Med 2006;35(2):41-6.

2. Bruni LF, Cruz AAV. Sentido cromático: tipos de defeitos e testes de avaliação clínica. Arq Bras Oftalmol 2006;69(5). doi: https://doi.org/10.1590/S0004-27492006000500028

3. Porto CC. Semiologia médica. Rio de Janeiro: Guanabara; 2014.

4. Guyton AC, Hall JE. Tratado de fisiologia médica. Rio de Janeiro: Elsevier; 2011

5. Longo DL. et al. Medicina interna de Harrison. Porto Alegre: AMGH; 2013.

6. Dantas AM, Zangalli AL. Neuro-Oftalmologia. Manuais básicos CBO. Rio de Janeiro: Guanabara Koogan; 2009.

7. Tasman W, Jaeger EA. Duane's ophtalmology. Philadelphia: Lippincott Will \& Wilk; 2005.

8. Dantas AM. Doenças da retina. Rio de Janeiro: Cult Méd.; 1996.

9. Adam Netto A. et al. Prevalência de discromatopsia no exame admissional para seleção de funcionários de uma indústria química na cidade de Tubarão. Ar Ct Med 2005;34(3):58-62.

10. Bronte-stewart J, Foulds WS. Acquired dyschromatopsia in vitamin A deficiency. Mod Probl Ophthalmol 1972;11:168-73.
11. Gheorghiu M. The pathogenesis of diabetic dyschromatopsia. Oftalmologia 1996;40(1):11-5.

12. Dantas AM, Moreira AT. Oftalmologia pediátrica. Rio de Janeiro: Clt Méd.; 2006.

13. Vaughan DG, Asbury T, Riordaeva P, Whitcher JP. Oftalmologia Geral. Porto Alegre: Artmed; 2010.

14. Calliari JV. Rastreamento de discromatopsia em estudantes do ensino básico de uma escola da rede pública municipal de Florianópolis. Florianópolis: Universidade Federal de Santa Catarina; 2007.

15. Neumaier R. Prevalência de discromatopsia em estudantes de medicina na Universidade Federal de Santa Catarina. Florianópolis: Universidade Federal de Santa Catarina; 2005.

16. Grassivaro Gallo P, Panza M, Viviani F, Lantieri PB. Congenital dyschromatopsia and school achievement. Percept Mot Skills 1998;86(2):563-9.

17. Teixeira FLF, Magalhães SA, Migueis LML, Castro FMC, Leite JA. Prevalência de discromatopsia congênita em estudantes do Noroeste Fluminese. São José dos Campos: Universidade do Vale do Paraíba, 2010.

18. Lima, AA, Biberg-Salum TG, Comarin MR, Kohl, EM. Rastreamento de ametropias e discromatopsias em estudantes do Ensino Fundamental de uma escola da rede pública municipal de Campo Grande-MS. Anuário da Produção de Iniciação Científica Discente; 2012.

19. Piccinin MRM, Cunha JFB, Almeida HP, Bach CC, Dossa ACGGOD, Silva RF, et al. Baixa prevalência de discromatopsia, pela 4a edição do teste pseudoisocromático HRR (Hardy, Rand e Rittler), da população indígena de etnia Terena da aldeia Lalima na região de Miranda: Mato Grosso do Sul. Arq Bras Oftalmol 2007;70(2):259-69. doi: https:// doi.org/10.1590/S0004-27492007000200014.

20. Rubin LR, Lackey WL, Kennedy FA, Stephenson RB. Using color and grayscale images to teach histology to colordeficient medical students. Anat Sc Ed 2009;2(2):84-8

21. Dargahi H, Einollahi N, Dashti N. Color blindness defect and medical laboratory technologists: Unnoticed problems and the care for screening. Ac Med Iran 2010;48(3):172-7.

22. Stoianov M, De Oliveira MS, Dos Santos Ribeiro Silva MCL, Ferreira MH, De Oliveira Marques I, et al. The impacts of abnormal color vision on people's life: an integrative review. Qual Life Res 2018. doi: 10.1007/s11136-018-2030-1.

23. Wayhs LF, Adam Netto A, Darugna M. Prevalência de discromatopsia em motoristas do transporte coletivo da Grande Florianópolis. Rev Bras Oftalmol 2002;61(2):115-9.

24. Campbell JL, Spalding AJ, Mir FA, Birch J. Doctors and the assessment of clinical photographs: does vision colour matter? Br J Gen Pract 1999;49:459-61.

25. Braunwald E. Medicina interna. Rio de Janerio: Hill Interamericana; 2009.

26. Ishihara S. Series of plates designed as tests for colourblindness. Tokyo: Handaya Hongo Harukich; 1997.

27. Cumberland P, Rahi JS, Peckham CS. Impact of congenital colour vision deficiency on education and unintentional injuries: findings from the 1958 British birth cohort. British Med J 2004;329(7474):1074-5.

28. Espinda SD. Color vision deficiency: a learning disability? $J$ Learning Disabilities, 1973;6(3):163-6.

29. Melo DG, Galon JEV, Fontanella BJB. Os "daltônicos" e suas dificuldades: condição negligenciada no Brasil? Physis 2014;24(4):1229-53. 